\title{
The Making of a Sacred Place: An Example of Constructing Place Identity in the Contemporary Mentality
}

\author{
Reet Hiiemäe
}

\begin{abstract}
Department of Folkloristics, Estonian Literary Musem; Center of Excellence in Estonian Studies reet@folklore.ee
\end{abstract}

\begin{abstract}
In the recent decades Kassinurme Hills in the county of Jõgevamaa (Estonia) have served as a crystallisation point of mythological and other expectations of various groups and individuals. I will show how fragments of archeological and historical evidence, folk legends and various national symbols have been woven into a unique whole that makes up Kassinurme Hills as a sacred place, yet I will also show how the very components are de-coded and interpreted differently by distinct groups of people, giving rise to debates about authenticity and place identity issues. Emerging contradictions on this level cause certain adjustments - some groups and individuals stop visiting Kassinurme and find new sacred places that are more in accordance with their needs and expectations, yet some visitors may find their "authentic" sacred place in Kassinurme namely because of the newly constructed meanings and images.
\end{abstract}

Keywords: sacred places, place identity, place lore, autheticity

In the contemporary Western society, an ever-increasing proportion of time is spent in places that Marc Augé calls non-places (e.g. supermarkets, traffic jams, locations that we access through computers or TV). To counterweight this trend, there is an increasing desire and need among people for "authentic" places, or places that offer "authentic" experiences and emotions. Yet the category of the "authentic" is defined variously by different social groups (and even by researchers). Authenticity problematics has been thoroughly analysed by folklorist Regina Bendix, who in her book "In Search of Authenticity" talks about creating a market of identifiable authenticities in the contemporary society (Bendix 1997: 3). Several authors have pointed out the interactive character of society and space. Human geographers and sociologists Derek Gregory and John Urry argue that "social relations create spatial relations and spatial relations create social relations" (Gregory \& Urry 1985: 13). In ac- 
cordance with Jean Baudrillard, Bendix states that the genuine and the spurios are converging, their identities being separable only by their narratives (Bendix 1997: 4). Hence, the narrative attached to a place plays the decisive role in if and how the identity of a person is anchored to a place.

Debates about narratives and beliefs connected with authenticity of places are also one of the main topics of this article and, based on these debates, conclusions are drawn about ways of constructing place identity and about the notion of "sacred" among certain groups and individuals. The place that I have chosen as an example of such construction mechanisms, Kassinurme Hills, is situated in Eastern Estonia in Jõgevamaa county. One of the reasons why I chose to write about Kassinurme is the fact that I have seen closely its step-by-step development in the recent more than ten years and participated in several events that have been organised there (most recently in the festival Mytofest in August 2013), also I have been in contact with a number of people who have shared their experi-

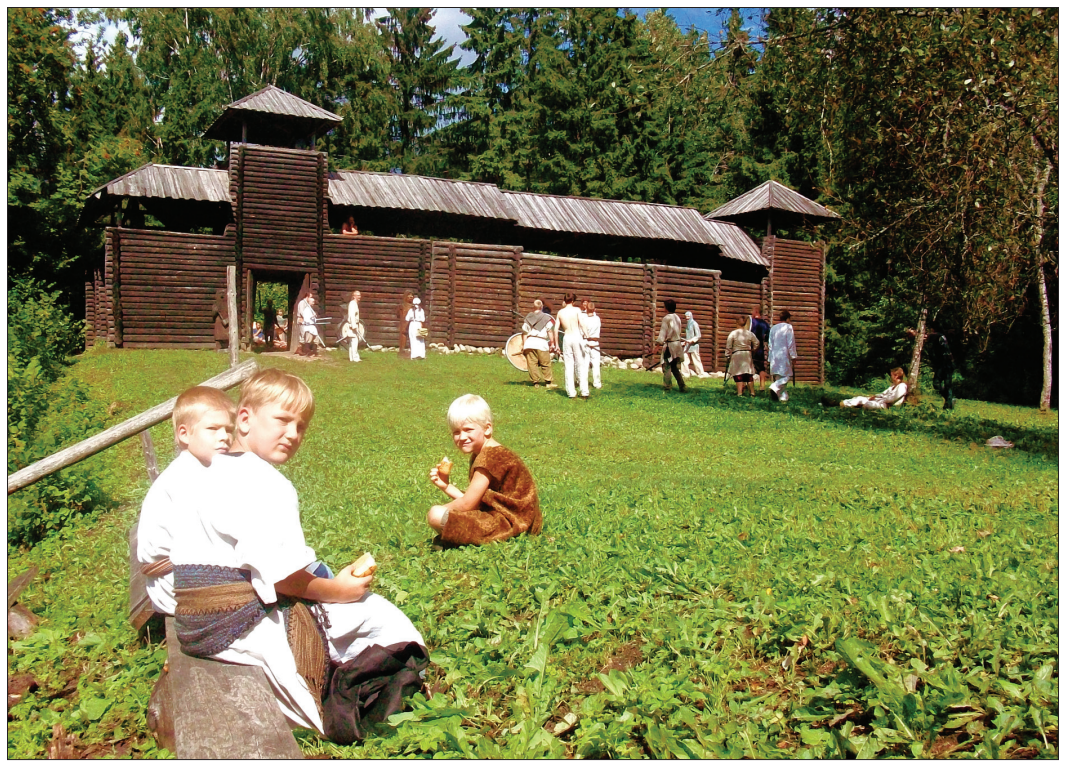

Figure 1. Kassinurme Hills with a wooden stronghold. 
ences in connection with this place (I have conducted 25 interviews and followed numerous postings in internet forums and newspaper commentaries about the topic).

In the following I will show how fragments of archeological and historical evidence, folk legends and various national symbols have been woven into a unique whole that makes up Kassinurme Hills as a sacred place, yet I will also show how the very components are de-coded and interpreted differently by distinct groups of people, giving rise to debates about authenticity and place identity issues.

\section{Kassinurme Hills as a Sacred Place}

A visitor who first arrives in Kassinurme Hills can see just some hills surrounded with forest, a couple of water ponds and big stones, everything else is manmade in the recent 20 years. What then makes it a sacred place?

In order to call a place a sacred place, two conditions must be fulfilled: first, there must be a place, and second, at least one person who thinks that it is sacred or has been sacred in the past. Actually, any place that is perceived as meaningful by an individual or a group can potentially become a sacred or a supernatural place. However, not all places that have suitable qualities for becoming sacred places, will become such places. Also the ideas about what characteristics should a place possess in order to become a sacred place and the amount of personal belief connected with it, change in time. But the need to perceive some places as sacred or supernatural, and share this knowledge with a certain group or groups is without doubt still topical in the contemporary world.

In the following I will use Kassinurme Hills as an example of a contemporary sacred place but many tendencies that I have observed are also true with other sacred or supernatural places in Estonia and elsewhere (cf. Gustafsson 2000 about trends of mythologising certain places and historical periods in Sweden, and Bedynski/ Mazur-Hanaj 2011: 174ff. about the mythologising of the Attila Hill in Hungary). However, insofar I have found only few works that analyse the complexity of constructing a sacred place through so many different prisms. 
In the recent decades Kassinurme has served as a crystallisation point of mythological and other expectations of various groups. As prerequisite for functioning in such a role, the hills join several attractive components:

- natural-geological (the hills have been shaped by the ice age),

— settlemental (proven settlement from about 6000 years ago),

- visual (dramatic landscape forms, a newly reconstructed wooden stronghold with wooden sculptures of mythological characters; a separated holy grove with impressive entering gates, big stones and wooden wheel crosses),

- mythological (several folk legends about Kassinurme are connected with the mythological giant Kalevipoeg, who is a popular figure in Estonian traditional folklore and who later, in the second half of the 19th century, became the main character in the Estonian national epic Kalevipoeg).

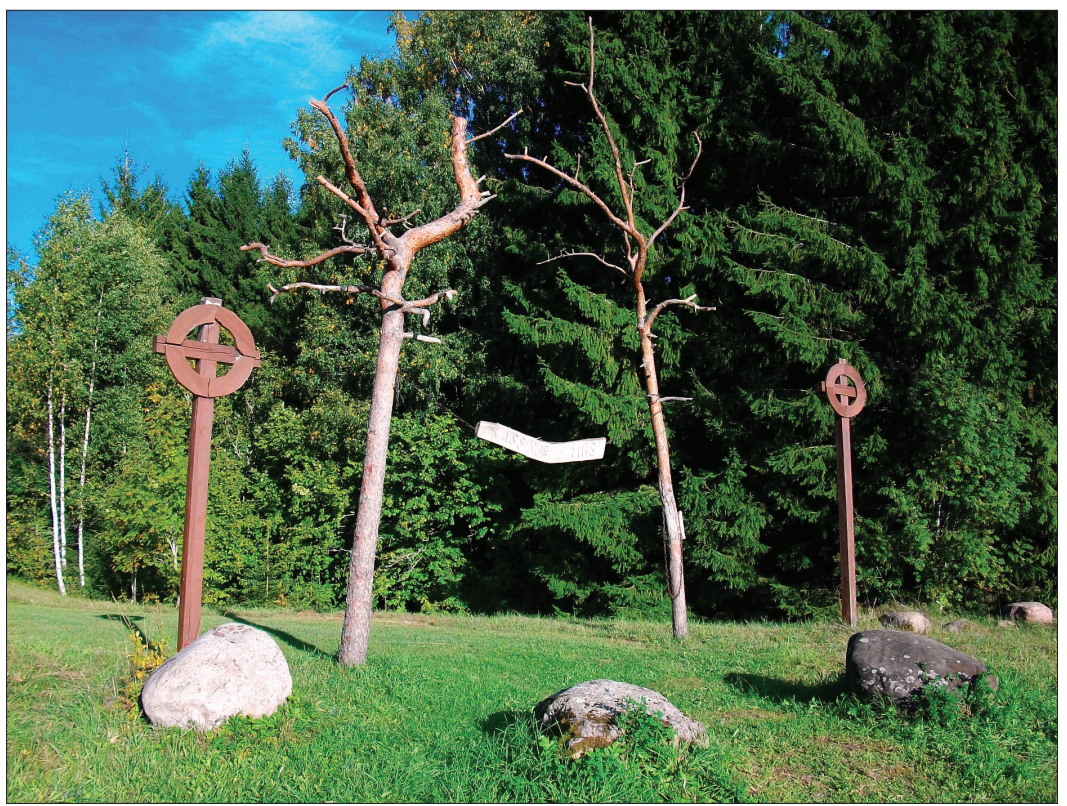

Figure 2. Entrance to the holy grove in Kassinurme. 
- spiritual (in the recent time, the place is claimed to be an ancient cult place, centring around a "powerful energy pillar" - an expression that is characteristic to the modern new age vocabulary).

The visual aspect is artfully combined with the mythological - there are newly added wooden figures of warriors, mermaids, animals, etc. that make the place look "ancient" and add a supernatural touch. The entrance of the holy grove is marked by a wooden gate, clearly indicating its borders on the landscape. The current visual atmosphere is supported by more than 100 years old legend texts that describe encounters between mythological beings and people in Kassinurme. The following two example texts from the manuscripts of the Estonian Folklore Archives are used in the internet materials about Kassinurme Hills:

By a legend Kassinurme Hills were formed by Kalevipoeg, who brought sand in his leather apron and piled it up here. The well is called his washing basin. In the surroundings a lot of small hollows, so called Kalevipoeg's handprints and the mark of his horse's hoof, can be found. $200 \mathrm{~m}$ from the biggest hill, in the forest, a stone has a red stripe on it like a trace of a sling; it is Kalevipoeg's Slingstone. (Palamuse 1896)

They say, this well [in the Kassinurme Hills] has no bottom at all. In 1860-ies, when there was a very dry summer, and some wise people suggested that old wives should measure the deepness of the well - then the rain would surely start soon again. Old wives of Patjala and all ropes were collected from the village. An iron kettle was put on one end of the long rope, a stone was put into the kettle to put on weight. The rope sank unbelievably deep.

They were not able to reach the bottom and the rope with the kettle was pulled out. Yet instead of the stone a bloody head of an ox was in the kettle. And there was a voice that said "Should you try to put in the kettle once again, I will pull you all down." After that the frightened wifes left measuring. Also old people say that oxes and cows sometimes have run into the spring and have never come back. In spring time people have seen water spirits sitting there and combing their head. (Palamuse 1896 - used in the Wikipedia article about 
the stronghold of Kassinurme: http://et.wikipedia.org/wiki/ Kassinurme_linnus).

\section{History of Kassinurme Hills}

In the following the history of Kassinurme Hills should be outlined shortly. 5000-6000 years ago an ancient settlement was established and about 3000 years ago a wooden stronghold was built there, findings prove human activity until the beginning of the 13th century. There is almost no information about the time inbetween but in the second half of the 19th century, during the period of national awakening in Estonia, Kassinurme Hills became a place for folk gatherings, festivals and students' daytrips. In the first period of Estonian independence (1918-1940) various cultural events took place, like theatre plays or choir singing events. During the Soviet time the social life and organising of cultural events in the surrounding villages ceased, the Kassinurme Hills grew into bushes. Only in 1989 (together with new signs of national awakening before Estonia regained independence in 1991) new initiative came from a local NGO to clean up; a big swing and fire places were built, later a fragment of the wooden stronghold was erected. Parallelly, cultural events started taking place again, many of them connected with folk culture, for example theatre plays, celebrations of special days in the folk calendar (like Shrove Tuesday sledge-rides, St. George's Day, Midsummer Day), warrior role plays (e.g. the reconstruction of the famous Battle of the St. George's Night with hundreds of participants). The most elaborated event - a special festival named Mytofest with the idea to reconstruct ancient Estonia and its culture - is organised yearly, ${ }^{1}$ attracting hundreds of visitors, yet it should be emphasised already beforehand (and this is also the observation of the festivals' two organisers whom I interviewed) that for the majority of participants of Mytofest the emphasis is rather on fun and imagination, not that much on authenticity.

These are the facts. But there is also a more poetic and interpretative kind of history that is more based on personal perceptions and cognitions of people. 


\section{History of Kassinurme Hills - Imagined}

All popular sources (web pages, tourism prospects) stress that namely the holy grove or cult place of Kassinurme is thousands of years old, although there is no such archeological evidence. The web page of Forest Society of Jõgeva (the NGO that has been dealing with reconstructing the place since 1989) informs us as following:

According to the archeological investigations, a permanent settlement was established here 6000 years ago. Our ancient forefathers found on the territory of the holy grove an emanation place of Earth energy and started exercising cultic activities. In order to protect themselves from evil forces, a wooden stronghold was erected close to the holy grove. [---] This stronghold here has never been conquered due to its peripheral location. (http://www.kassinurme.ee/kassinurme.html)

In this short description we can see several typical elements that are used to mythologise sacred places:

- the perception of long historical continuitation ("our ancient forefathers"); the nostalgy of ancient times;

- overturn of history: archeological excavations have indeed found remnants of ancient settlement that make it possible to assume that there could have been also a nearby cult place; yet in the description above the cult place is described as the starting point that preceded everything else; on the real landscape the wooden stronghold and the holy grove are separated from each other by ca. 200 meters, yet in everyday communication they are spoken of as one and the aura of an ancient cult place has been carried over to the Kassinurme Hills as a whole. Here the theory of "the social framework of collective memory" by sociologist and anthropologist Maurice Halbwachs could be pointed out that has been also elaborated in the works of the historian Peter Burke. Burke notes in accordance with Halbwachs that human groups determine what is worth of remembering and how it should be remembered. Individuals identify with such events and symbols that are significant for the group. Hence, they often "remember" well things that they have actually not experienced personally (Burke 2006: 53); 
- the unconquered stronghold as symbol of the heroic strength and love for freedom of Estonians; such classical symbol-laden tropes like 'the ancient Estonians', 'battles for freedom', 'ancient cult and sacrificial place' that can be connected with Kassinurme provide a suitable background to turn Kassinurme Hills into a place of identification that is acceptable to many people;

- inspite of the desire to show a historical continuation, the information is interpreted in the framework of new age spirituality and esotericism: the text says that ancient people were aware of the emanation of Earth energy or an energy pillar, yet in the Estonian older folklore there is no sign of a tradition to create cult places according to the existence of energy pillars. Even the expression "energy pillar" has emerged only in the recent decades and the discourse of energy pillars has become popular just in the modern esoterical tradition. Reflections of this narrative of energy pillars can be found in the newspaper interview with a well-known Estonian actress, Ülle Lichtfeldt, who has participated in a theatre play in Kassinurme: "We played two years in Kassinurme that is one of the best-known locations of energy pillars in Europe" (newspaper "Põhjarannik" 6.2.2009).

Based on these "facts" or pre-knowledge, often personal empirical perception or recognition of the "right place" (i.e. the feeling that the place is indeed a sacred place) automatically arises. People who express this understanding seem not to feel the need to ask themselves how they have obtained this perception.

When we look at internet esoteric or role-players' forums and also on commentaries that are written to online newspaper articles about Kassinurme Hills, still two main categories of opinions about sacred places may be observed:

- people who find that the deciding element what makes a sacred place a sacred place is the personal feeling of sacredness connected to a given place, therefore it is not important if it is a place that has been used as a cult place in ancient times or has been just newly built. An example: "If many people perceive that it is a right place (and especially if they come to this opinion independently), in this case it is for me quite surely a more convincing 
argument than many others" (roleplayers' forum on http://www. dragon.ee, July 2008).

- people who find that a sacred place must have a hundreds (or even thousands) of years long history of being used as a sacred place. An example: "The name 'sacred place' deserves a place that our forefathers chose as a sacred place and that has been used as such for centuries. In Kassinurme they just took recently a piece of land in a convenient place, called it a sacred grove and created suitable decorations. For me this is not enough to call it a sacred grove" (http://www.dragon.ee, July 2008).

There are people who go to holy groves for religious purposes even nowadays, yet a significant part of the contemporary perception of sacred places and the identity-building connected to it has just to do with entertainment and fun. The relationship with a holy grove is not any more the question of life and death because people don't believe any more that worshipping supernatural beings in a holy grove or other sacred place is necessary for granting their survival. Folklorist Roger Abrahams points out that in case of modern reconstructions of ritual experiences the use of the notion 'sacred' may not be necessarily reasonable altogether because of the tendency of profanisation (Abrahams 2003: 213). However, while choosing their favorite places, be it mainly for fun, identity-building or belief purposes, many people still seem to need the component of the unexplainable and mystical, at least an imaginary connection with the mythical past, the possibility to reconstruct a certain continuity of sacredness and a heroic mental narrative.

\section{The Holy Grove - a Powerful Symbol of Estonian National Identity}

A concept that has been loaded with many of the meanings mentioned above is the holy grove (about mythologizing and sacralizing of oak groves see also Heinapuu 2010). Although the area that is called the holy grove of Kassinurme constitutes only one part of the whole Kassinurme Hills, the whole place is often referred to as "the holy grove of Kassinurme" in conversations as well as on websites.

Since the national awakening in the second half of the 19th century there is the tendency to idealize holy groves - they are perceived as 
an evidence of the existence of a well-developed pre-Christian culture of Estonians (the Christianisation of Estonia took place in the 13th Century). Drawing this connection leaves aside all changes in culture, folk belief and mentality during centuries that followed the Christianisation; it is perceived like a spatial shortcut: whenever we go to holy groves and act like forefathers, we are brought back to the heroic "pagan times". Yet the behaviour that most people practice in the holy groves (including the holy grove of Kassinurme) is mainly formally imitating: they leave "sacrificial" coins on the stones and bind lints and ribbons on trees and bushes. An alienation from the old nature religion can be seen in the fact, that there are also many plastic ribbons hanging on the trees. When I ask people why they bind such ribbons, the answer is: "Because this is the tradition", "This was the tradition of old Estonians" (visitors of Kassinurme Hills, 2012). Yet many are not aware why "old Estonians" did so, such binding has often no religious background. However, already the mere act of imitating the forefathers gives one the feeling of the continuously shared identity with the forefathers.

In addition, ancient looking pseudo-folkloric innovations as part of role plays are invented in the holy grove of Kassinurme, e.g. stagy sacrificing of virgins, group charms accompanied by a dance with burning torches, and other rituals. A former organiser of the role plays explains the reasons of such behaviour as following:

Kassinurme would do as a good place of roleplaying also without the holy grove, however, the holy grove is a good "selling argument"; as it is just there, it is handy to include rituals that are played there as part of the role play, there are, for example, rituals that are used for increasing magical skills. I personally don't think that they are ok, they just don't fit together with the holy grove. (Man, 30 years old; 2012)

The opinion of an active role player confirms this explanation:

"The holy grove adds a mystical aura to the role play" (Man, 25 years old; 2012).

However, such innovations may change the behaviour of some other visitors regarding the holy grove. The viewpoint of a local villager whom I interviewed was following: "Visitors who take the holy grove more seriously give up visiting it because there is always some kind of play and action going on there" (woman, 33 years old; 2012). 
In some cases the conflict between competing interests may be expressed even sharper: on a summer day of 2010, I visited Kassinurme Hills with my husband and two little sons. We saw a group of people in ancient-looking costumes by the stronghold and one man from the group approached us, saying: "We have booked the compound for our event, therefore we would ask you to leave it as soon as possible. Didn't you see the notice on the entrance?" Later we saw indeed a paper on the entrance gate with the laconic text that the place was booked for the whole day. The group was re-enacting the life of ancient Estonians, without, however, paying attention to the circumstance that it was obviously not a tradition among our forefathers to "book" sacred places for their private events. Hence, a selective identification with the "ancient" traditions is used in constructing the modern sacred place experience.

\section{The Reconstruction of the Battle of the St. George's Night}

Another very powerful and meaningful concept for the Estonian identity-building is the Battle or Rebellion of the St. George's Night. Historically (to outline a simplified version), it was an organised uprising of Estonian peasants against German and Danish landlords that started on April 23rd, on the St. George's night in 1343 and took place mainly in Northern and Western Estonia. However, it has become the symbol of freedom of Estonians altogether (more on the narrative of the Great Battle for Freedom of Estonians and the respective mnemohistory see Tamm 2008: 505ff.). The symbol is also powerful because of its continuity - in the period of the national awakening in the second half of the 19th century several writers wrote their heroic interpretations of the events of St. George's Night, most important and popular of them being Eduard Bornhöhe's 'Tasuja' [The Avenger] (1880); talking about this uprising was not forbidden even in Soviet time because it was possible to interpret it as the rebellion of proletarian peasants against exploiters from upperclass. In Kassinurme Hills it can be already called a tradition to organise warrior role plays every year, aiming to reconstruct the Battle of the St. George's Night.

However, the majority of role players say that this battle is a rather playful reconstruction and its main purpose is fun. A former organiser of the roleplays comments: "The St. George's Battle roleplay is 


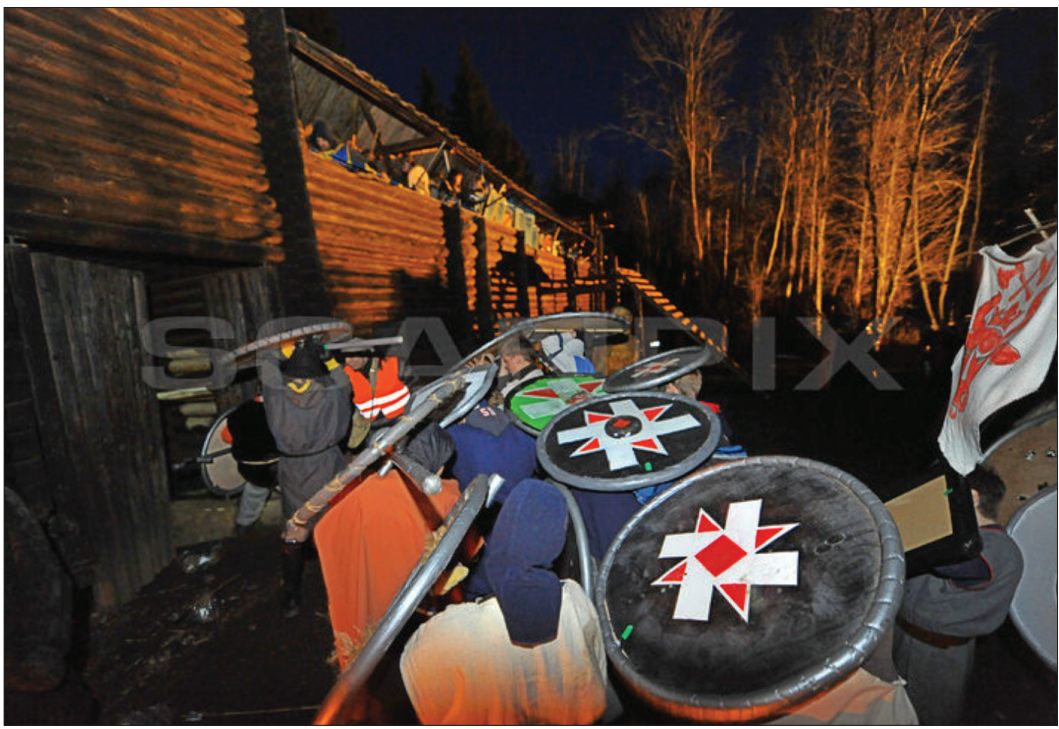

Figure 3. Warrior roleplay in Kassinurme Hills.

pure play, participants don't aim to present historical truth." He also explains the criteria that are followed while chosing clothing and other equipment:

Some re-enactors [a group that tries to reconstruct lifestyles of certain periods as authentically as possible] also come here with their whole equipment but it is rather because of vainglory. By LARPs [Live Action Role Players] it is enough when they avoid speaking with cell phones and cover themselves with an old-looking cloth. At the same time the rules of LARP have changed in time. Regarding equipment there are inevitably compromises needed between safety, authentity and the finances of the player. (Man, 30 years old; 2012)

Yet even a tradition that is mainly reconstructed for entertainment purposes has its authenticity demands in the eyes of many - e.g. in the majority of online commentaries to an article and photos in the newspaper "Postimees" (April 2012) about this event one could notice the verbal dictation by the readers that such a warrior role 
play should only take place in a "right place" (and therefore in a place that has an at least hundreds of years old cultic history); a warrior should wear authentically looking leather and linen clothes, otherwise he is not a "right warrior" and it is not a "right battle". To some extent, the role players themselves also compete about who looks most "authentic". In a word, there is a claim to reconstruct as authentically as possible an event that has actually never happened in this place - as already said, the historical battles connected with the St. George's rebellion took place in North and Western Estonia and in majority of cases not in sacred places.

In the online commentaries one can often observe a so-called negative reconstruction - the commentators know exactly how things should not be, yet they do not mention, how they should be. Folklorist Kristin Kuutma notes about such models of identity building while referring to the cultural theorist Homi Bhabha: "The representation of the spiritual image of identification is always spatially and physically split - on the one hand, it grants the presence of something or someone that or who is actually not there and is at this point of the timespace not present. And on the other hand, an equal temporal shift occurs: it is the representation of the point of time that is always somewhere else, but that is being attempted to be repeated" (Kuutma 2008: 23; Bhabha 1993: 73). Hence, the self-cognition of people is based namely on elements that are not there or who they are not (Kuutma 2008: 23). However, by negative as well as positive reconstruction, places and people are perceived to be obliged to fit with the stereotypes that have been accepted by the repertoire of the social memory of a culture (cf. Burke 2006: 61). The appearance of the participants of the battle roleplays in Kassinurme Hills obviously did not fit with the common stereotypes of the holy grove and the battle for freedom of the St. George's Night, therefore the critical opinions of online commentators were rather expectable. Below are some examples of commentaries from the newspaper Postimees (April 2012):

"When I look at these ugly stained policemen helmets and these funny paper and cardboard shields, they would no way remind me of the St. George's Battle!" 
"A role play may easily become playing fools, like in the parliament... An ancient warrior with eye glasses and plastic bottles, a mobile phone vibrating under the clothes?"

"Quite a strange bunch of hairy and feathery creatures. Well, I have nothing against it that young people rave a bit, but why to connect all this with the St. George's Battle? The real history should be still separated from hobbits and vampires!" "Cosmic warriors in the St. George's Battle? I guess I have to take a hangover cure!"

"What does it all has to do with St. George's Night? Or what have these babbling and bear-drinking youngsters with swords from stain and cardboard to do with the ancient battle for freedom? This role play is really a joke... like this they should rather play at home" (Postimees 2012)

It is interesting to point out that while many cultural researchers have attempted to interpret cultural reality through the analogies and rules of play (e.g. Geertz 2003: 37jj), the commentators in the case of Kassinurme have based their interpretations of and requirements to a playful event on (at least alleged) cultural and historical reality. Yet the demands of authenticity have also their limits. The main objections of commentators are against plastic clothes and weapons, yet arriving to the event in cars and having a parking lot full of cars immediately besides the "ancient" battle ground is perceived as acceptable.

A new aspect by modern sacred places and by Kassinurme Hills as well is the fact that nowadays people are free from the constraints of fixed religious traditions and sedentary lifestyle, they are much more mobile. Therefore they have (unlike in the past) much more choices about which places they want to connect their identity and expectations with. For example, participants of Kassinurme warrior plays come from all over Estonia and even from other Baltic states. The modern individual has the freedom of choice and the connection with a place is often not created "by birth" (i.e. through local traditions directly passed on by older members of a group) but mediated via mass media. At the same time, modern mass media enables us the use of identity-building elements from a very manyfaceted religious, esoterical and historical knowledge from all over the world. Anthropologist Arjun Appadurai has coined the term de- 
territorialisation for such cultural processes, meaning ethnic groups and traditions which increasingly operate in ways that transcend specific territorial boundaries and identities (Appadurai 1991: 192). A parallel may be drawn with pilgrimage tourism - many people in Estonia and other industrial countries are - often through tourist advertising materials - aware of famous sacred places abroad (e.g. Jerusalem, mount Sinai in Egypt) and visit them, but may not have heard from or not be interested in small sacred places in the neighbouring village. I agree with authors (e.g. Gustafsson 2000: 164) who have noticed that role-playing events connected with certain historical places are often visited mainly by outsiders and not by locals who would actually have former ties with the place; moreover, to some locals, indigenous local identity is even better expressed by dissociating from the festival crowd or group event than by being part of it.

\section{Conclusions}

The primary function of sacred places like Kassinurme Hills in modern Europe is obviously not to fill some inevitable religious needs of people, yet - as it was shown also on the example of Kassinurme Hills -, still such places are needed as supporting tools of identity building. Mythological or supernatural background of such places is often just part of fun, yet it is still felt important in order to complete the place experience as a whole. However, the reconstruction by every party (in the case of Kassinurme Hills, by LARProleplayers, re-enactors, artists, local people, individual visitors, online commentators) is somewhat different and contains various authenticity demands. Emerging contradictions in these demands cause some groups and individuals stop visiting Kassinurme and find new sacred places that are more in accordance with their needs and expectations, yet some visitors may find their "right place" in Kassinurme namely because of the newly constructed meanings and images. 


\section{Acknowledgements}

Research for this article was supported by the Centre of Excellence in Estonian Studies (CEES, European Regional Development Fund) and is related to research project IUT 22-5 (Estonian Research Council).

\section{Notes}

${ }^{1}$ A video about Mytofest 2013 can be found under: http://www.youtube. com/watch?v=v7O9irNLsys (18.02.2017).

\section{References}

Abrahams, Roger D. 2003. Identity. Eight words for the study of expressive culture. Feintuch, Burt (ed.). Urbana \& Chicago: University of Illinois Press, pp. 198-219.

Appadurai, Arjun 1991. Global ethnoscapes. Fox, Richard G. (ed.). Notes and queries for a transnational anthropology. Recapturing anthropology. Working in the present. New Mexico: School of American Research, pp. 191-210.

Augé, Marc 1995. Non-places: Introduction to An Anthropology of Supermodernity. London \& New York: Verso

Bedynski, Wojciech \& Mazur-Hanaj, Remigiusz (eds.) 2011. The tree, the well and the stone: sacred places in the cultural space of Central-Eastern Europe. Warsaw: In crudo.

Bendix, Regina 1997. In Search of Authenticity. The Formation of Folklore Studies. Wisconsin: University of Wisconsin Press.

Bhabha, Homi K. 1993. Interrogating Identity: Frantz Fanon and the Postcolonial Prerogative. The Location of Culture. London \& New York: Routledge, pp. 57-93.

Burke, Peter 2006. Kultuuride kohtumine. Esseid kultuuriajaloost [Meeting of cultures. Essays about cultural history]. Tallinn: Varrak.

Geertz, Clifford 2003. Omakandi tarkus. Esseid tõlgendavast antropoloogiast [Local knowledge. Essays about interpretive anthropology]. Tallinn: Varrak.

Gregory, Derek \& Urry, John 1985. Social relations and spatial structures. Gordonsville: Macmillan. 
Gustafsson, Lotten 2000. Medieval selves and current communities: playing with identity at an intersection of rootedness and mobility. Pertti J. Anttonen (ed.). Folklore, Heritage Politics and Ethnic Diversity: A Festschrift for Barbro Klein. Stockholm: Mångkulturellt Centrum, pp. 158-176.

Heinapuu, Ott 2010. Taara tammikud: ideaalse pühapaiga tung tekstist maastikule [How a sacred landscape migrates from a vision into the environment]. Acta Semiotica Estica, 7, pp. 102-138.

Kuutma, Kristin 2008. Küsimusi identiteedist - teoreetilisi trajektoore kultuuriuuringus [Questions on identity - theoretical trajectories in cultural studies]. Paar sammukest. XXVI Eesti Kirjandusmuuseumi aastaraamat. Tartu: EKM Teaduskirjastus, pp. 15-28.

Tamm, Marek 2008. History as cultural memory: Mnemohistory and the construction of the Estonian nation. Journal of Baltic Studies, 39 (4), pp. $499-516$. 


\section{ELM Scholarly Press \\ SATOR 18}

http://dx.doi.org/10.7592/Sator.2017.18

\section{BALKAN AND BALTiCUM}

Current Studies in the Postsocialist Space

Edited by

Ekaterina Anastasova and Mare Kõiva

Tartu 2017 
Editors and compilers: Ekaterina Anastasova, Mare Kõiva Series "Sator" editor: Mare Kõiva

Language editors: Liisa Vesik, Lii Liin

Cover photo: Jaak Kikas, 2017 "Autumn in Tartu"

International committee

Tiiu Jaago (Tartu University); Reet Hiiemäe (Estonian Literary Museum); Mare Kalda (Estonian Literary Museum); Tarmo Kulmar (Tartu University); Nikolay Kuznetsov (Estonian Literary Museum); Aado Lintrop (Estonian Literary Museum); Emily Lyle (School of Scottish Studies in Edinburgh); Mirjam Mencej (Ljubljana University); Jonathan Roper (Tartu University); Marju Kõivupuu (Tallinn University); Ülo Valk (Tartu University); Tatjana Vladõkina (Institute of Udmurtian History, Language and Literarture, Izhkar); Irina Vinokurova (Institute of Karelian History, Language and Literarture in Petroskoi); Ergo-Hart Västrik (Tartu University)

Supported by Estonian Academy of Sciences, Bulgarian Academy of Sciences, the Centre of Excellence in Estonian Studies (CEES, European Regional Development Fund) and is related to research projects IRG 22-5 (Estonian Research Council).

\section{$\boldsymbol{C} E \mathbf{E} \times \begin{aligned} & \text { Centre of excellence } \\ & \text { in Estonian Studies }\end{aligned}$}

Series "Sator. Artikleid usundi- ja kombeloost", 18 http://www.folklore.ee/rl/pubte/ee/sator/sator18/

ISSN 1736-0323 (online)

ISBN 978-9949-586-58-5 (printed)

ISBN 978-9949-586-61-5 (online) ISSN 1406-2011 (printed)

DOI: 10.7592/Sator.2017.18

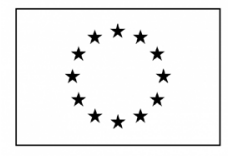

European Union European Regional Development Fund

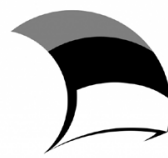

Investing in your future

\section{EUROPEAN UNION}

Regional Development Fund

Investing in your future
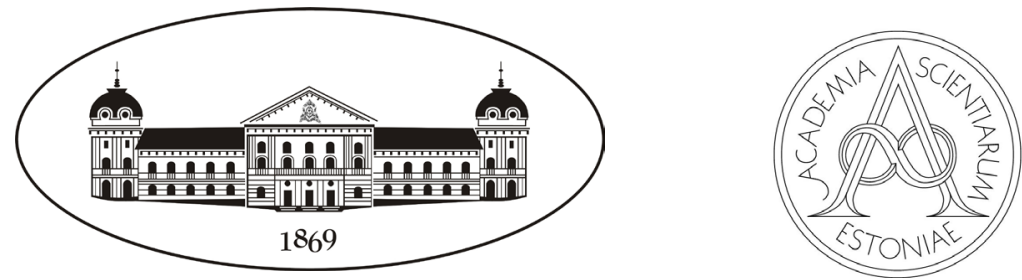


\section{Contents}

Preface

Mare Kõiva, Ekaterina Anastasova

CONSTRUCTING IDENTITY AND SOCIAL TIES

Ethnographic Studies on the Montenegrin

Festive Costume as a National Symbol

Sofiya Zahova

Social Ties of Bulgarians and Rudari in the Mediterranean Countries

Magdalena Slavkova

\section{RECASTING RELIGION AND \\ RELIGIOUS IDENTITY}

Contemporary Development of the Akyazili

Baba Tekke / St. Athanasius in Bulgaria

Yelis Erolova

Turkish Religious Identity in Bulgaria

94

in the Last Twenty-Four Years (1989-2013)

Mila Maeva

The Feast of Cyril and Methodius in Bessarabia and Crimea, Ukraine

Ekaterina Anastasova 
The Saints of Death in the Traditions

of the Balkan People

Rachko Popov

\section{CONSTRUCTING NEW SPIRITUALITY}

New Trends in the Study of Religion in Estonia -

Contemplations in the Grey Zone between

Religion and Science

Tõnno Jonuks

Constructing New Spirituality in Modernity -

the Case of the White Brotherhood in Bulgaria

Svetoslava Toncheva

Constructing Contemporary Periodical and

Occasional Rituals

Mare Kõiva

The Making of a Sacred Place:

221

An Example of Constructing Place Identity in the Contemporary Mentality

Reet Hiiemäe

\section{CHANGING TRADITIONS}

Bridge Over the Rainbow. Animal Burials and

Animal Cemeteries in Post-Socialist Estonia

Marju Kõivupuu

Simple Hide-and-seek at its Core: Play Features and the Game of Geocaching

Mare Kalda 